\title{
Women Entrepreneurial Innovative Behaviour: The Role of
}

\author{
Psychological Capital
}

\author{
Sunday Samson BABALOLA \\ Department of Psychology, Faculty of the Social Sciences, University of Ibadan \\ Ibadan, Nigeria \\ E-mail: ss.babalola@mail.ui.edu.ng; ssbabalola@yahoo.com
}

\begin{abstract}
This study investigated the influence of psychological capital on women entrepreneurs' innovative behaviour with 405 female entrepreneurs from Ibadan, Nigeria. The result indicates that women with high self-efficacy and internal locus of control scored higher on entrepreneurial innovative behaviour than women with low self-efficacy and external locus of control. There was also a significant relationship between highly educated women and lowly educated women. Women are encouraged to belief in themselves while their acquisition of higher education will provide impetus for growth and achievement in entrepreneurial innovative activities. Further studies in relation to task specifics are recommended.
\end{abstract}

Keywords: Innovative behaviour, self-efficacy, Women entrepreneurs, Psychological capital

\section{Introduction}

The tremendous significance growth of small firms towards the end of $20^{\text {th }}$ century has robed on women's employment status (Loveman \& Sengenberger, 1991; Acs \& Audretsch, 1999; Quince \& Whittaker, 2003). Initially, women's work has been centered in the home, whereas, these days women are now involved in income generating ventures that contribute economically to the family and community growth. Although, entrepreneurship is perceived as a "male" domain because its task are often associated with masculine behaviour (Dickerson \& Taylor, 2000; Verheul, Uhlaner \& Thurik, 2005). Females are however, now involved in entrepreneurial activities possibly not only as a means for economic survival but also as a means of positive social repercussions for themselves and their social environment (UNIDO, 2001). Thus, according to Lee and Venkataraman (2006), the involvement of females entrepreneurship may have arose from the disequilibrium between their aspirations and the perceived valuation of the labour market offers.

Despite many shortcomings and constraints, contemporary women are setting up their own enterprises, even in countries where economic decisions would normally be taken by the male head of the households. According to World Bank (1995) report, Nigeria is a good example of this phenomenon. This is because according to Hoffman (1974), women employment has some effect upon her domestic roles and her personality factors. Although, many of the problems reported for American women are common to those faced by Nigerian business women (Parikh, 1987). Nigerian female entrepreneurs, however face problems attributable to socio-cultural factors (Ehigie \& Idemudia, 2000; Ehigie \& Umoren, 2003; Kitching \& Woldie, 2004; World Bank, 1995). This is because some cultures and social traditions (like Yoruba, Ibo, Hausa, Bini) play a significant role in determining who becomes an entrepreneur. For instance, women are not expected to be involved in occupations that will take them outside their matrimonial home; rather they are expected to manage the family and "be submissive to their husbands" (Ehigie \& Idemudia, 2000). Nevertheless, women are increasingly expected to work due to completion of educational careers and decline of domestic work as an occupation (Ehigie, 2000). In addition, small-scale businesses are perceived as ventures that require less demand (Babalola, 1998). Possibly, this is why Berger and Byvinie (1989) found that female entrepreneurs are higher in informal sector than male entrepreneurs in Nigeria. Although, Kitching and Woldie (2004) opined that female entrepreneurs in Nigeria are hindered by a variety of barriers despite having made considerable advances. However, not all women that are involved in entrepreneurial venture turn out to be successful as possibility to make poor decisions regarding the factors relating to little or no innovative behaviour abound.

Innovation is the generation of ideas, its acceptance and the implementation of such ideas, which are either novel, or modification of existing processes, products or services (Babalola, 2006). Studies showed that it is one of the most critical capabilities that successful entrepreneurs should possess because it relates to the production or adoption of useful ideas and idea implementation (Kanter, 1988; Van de Ven, 1986) including re-structuring of existing or old products or ideas. Significant innovations allow companies to establish dominant competitive positions and afford newcomer companies an opportunity to gain an edge in the market (Erdil, Erdil \& Keskin, 2004). Researchers were of the view that innovative behaviour is related to the ability to generate ideas and the willingness and skill to work with these ideas (Scott and Bruce, 
1994; West and Farr, 1989). To Scott and Bruce (1994), individual innovation begins with problem recognition and the generation of ideas or solutions, either novel or adopted, as such, making entrepreneurial innovation results in creative expression of individuals. Similarly, West and Farr (1989) defined innovative behaviour as 'all individual actions directed at the generation, introduction and application of beneficial novelty at any organizational level'.

Some studies on innovation collapsed the suggestion and implementation of ideas into single-measure (Scott \& Bruce, 1994) as opposed to those that separate them into two-measures (de Jong \& den Hartog, 2003). The use of two-measures is because the factors that influence successful implementation tend to differ from those that influence the initiation of ideas (de Jong \& den Hartog, 2003). As the foundation of innovation is ideas, the study of innovative behaviour among women entrepreneurs should be of importance as 'there has been scanty attention on innovation at the individual and group levels' (West \& Farr, 1989). In addition, since there is little or no systematic empirical research on the level of innovativeness among women entrepreneurs', relying on generalized conclusion may lead to systemic error regarding the specific nature of women entrepreneurs.

\section{Literature Review}

In his theory of expectancy, Vroom (1964) proposed that a person's behaviour is motivated by the expectation that her behaviour will lead to certain outcomes, together with the values she places on those outcomes. He situated his theory on the notion that behaviour is a function of interaction of personality and the environment. Vroom's theory built on the concepts of valence, instrumentality and expectancy. Applying this to women entrepreneurs, it is expected that the level at which women will engage in entrepreneurial innovative behaviour is dependent on how well they desire growth (valence), their perceived probability that their efforts will lead to achievement of their goal (their enterprise growth) and that their innovativeness will have a positive effect on their enterprise. Nevertheless, a study by Cliff (1998) showed that women value personal considerations as more important than economic considerations for business expansion decisions. It can therefore be argued that the different approaches to venture creation and involvement among women entrepreneurs may lead to their enterprise expectancies (Brush, 1992; Cliff, 1998; Orser \& Hogarth-Scott, 2003).

To Weiner (1974) ability, effort, task difficulty, and luck are the most important factors affecting attributions for achievement. Attribution is classified along three causal dimensions of locus of control, stability and controllability. Locus of control is concerned with confidence in being able to control outcomes, which can be either internal or external. It is a personality predisposition, which describes an individual's perception of their ability to change a situation. McNairn and Mitchell (1992) refer it as a set of beliefs about behaviour. A belief in external control means a person believes an event is largely the product of forces beyond her control. A belief in internal control means a person believes an event is dependent upon her behaviour (Craig, Franklin \& Andrews, 1984). An individual with strong internally locus of control may tend to believe that she can influence and alter situation through the exercise of her skills and knowledge. Strong internal control tends to bring in self-confident. Hence, women entrepreneur with strong internal control is likely to seek opportunities to improve her enterprise by trying new techniques and technologies that will enhance its growth. The opposite is likely for the strong externally control individuals. Research has however demonstrated strong linkages between locus of control and behaviour in areas as diverse as physical and mental health, intellectual achievement, and entrepreneurship (Lefcourt 1981; Rauch \& Frese 2000; Sia, Hungerford \& Tomera, 1985; Van Kooten, Schoney \& Hayward, 1986). According to Rauch and Frese (2000), business owners have a slightly higher internal locus of control than other populations.

Other personal variable that is being assumed to influence women entrepreneurial innovative behaviour is self-efficacy. Self-efficacy has to do with how competent one feels in what one is doing. It is a person's belief on one's ability to successfully reach an expected goal as a result of one's actions (Bandura, 1997). It is also a motivational construct that has been shown to influence an individual's choice of activities, goal levels, persistence, and performance in a range of contexts (Zhao, Scott \& Hills, 2005). Thus, self-efficacy is assumed to have been accumulated through the development of complex cognitive, social, linguistic and/or physical skills that are obtained through experience (Bandura, 1982; Gist, 1987). Studies showed that high self-efficacy is essential to most human performance (Bandura, 1997; Bandura, Pastorelli, Barbaranelli \& Caprara, 1999; Sequeira, Mueller \& Mcgee, 2007). Thus, without a strong sense of self-efficacy, an individual has little incentive to act or to persevere in the face of difficulties (Bandura, 2002).

As Covin and Slevin (1991) and DTI (2001), studies identified self-efficacy and innovativeness as part of behaviour that are important in both policy and organizational contexts. So also, Cooper and Gascon (1992) found that individual variables (personality traits and demographic characteristics) were relatively poor predictors of survival and success let alone of specific organizational behaviour such as innovativeness. In contrast, Mumford and Gustafson's (1988) study suggested that education is important to innovation, while Schiller and Crewson, (1997) stated that education and experience were positively correlated with entrepreneurial performance. The present study is therefore designed to clarify the factors that influence women entrepreneurial innovative behaviour.

Women's socialization experiences have been used by social learning theorist (Hackett \& Betz, 1981) to explain women's lack of strong expectations of personal efficacy in relationship to many career related behaviours, thereby limiting the full 
attainment of their potential. To Bussey and Bandura (1999), a variety of factors may influence gender development (educational practices, occupational systems) while confirming that the differences in women and men are due to socialization practices. Thus, the reliance on the notion that enterprise creation is a male domain may make gender role pressures to influence perceived efficacy. For instance, Kalleberg and Leicht (1991) hypothesized that women were thought to engage in innovative behaviour less frequently whereas their study revealed that women were as likely to report business innovations as men were. It is possible therefore that with high self-efficacy women entrepreneurs are likely to excel and engage in innovative behaviour. Just as Wood and Bandura (1989) noted, high self-efficacy expectations regarding performance in a specific behavioural setting lead individuals to approach that setting, whereas low self-efficacy expectations lead individuals to avoid such setting. Bandura (1995) and Eden (1992) pointed out that individuals with low self-efficacy think and behave differently than people with high self-efficacy. All these attest the empirical findings (De Noble, Jung \& Ehrlich, 1999; Sequeira, et al., 2007; Zhao, Scott \& Hills, 2005) which concluded that individuals with high self-efficacy are more likely to engage in observable behaviour such as establishing a strong motivational link between self-confidence in performing entrepreneurial tasks and explicit behaviour regarding an enterprise venture. In this study, therefore the following hypotheses will be examined:

1. Women entrepreneurs with internal locus of control will significantly scored higher on innovative behaviour than women entrepreneurs with external locus of control.

2. Women entrepreneurs with high self-efficacy will significantly scored higher on innovative behaviour than women entrepreneurs with low self-efficacy.

3. Women entrepreneurs with high self-efficacy and internal locus of control will significantly scored higher on innovative behaviour than others in combined categories of locus of control and self-efficacy.

4. Highly educated women entrepreneurs will significantly scored higher on innovative behaviour than lowly educated women entrepreneurs.

\section{Methods}

\subsection{Research design}

The independent variables in this study are age, educational status, self-efficacy and locus of control while the dependent variable is entrepreneurial innovative behaviour. All the variables were measured using a questionnaire. The statistical tools used for analysis were $t$-test for independent measures and 2 by 2 ANOVA.

\subsection{Participants}

Four hundred and five (405) women entrepreneurs with age range 20-60 years and mean age of 38.39 years participated in the study. The women entrepreneurs were systematically selected from the population of women business owners in service cum product sector in Ibadan using the Business Premises Registration Record, which was obtained from Oyo State Ministry of Commerce and Industry, Nigeria. Ibadan is the capital city of Oyo state and has a population of 3 million. It is the largest indigenous city in Sub-Sahara Africa dominated by Yoruba speaking people, and is not different from what is obtainable in other Africa cities. (Mabogunje, 1967; NPC unpublished manuscript, 2004).

This category comprises of women designers, interior decorators, and producer and decorator of bridal materials, school proprietors and fashion designers. About sixty three percent of the participants $(254\{62.72 \%\})$ were highly educated (above secondary education- diploma, degree and postgraduate certificates) while lowly educated (primary and secondary certificates) comprised 151 (37.28\%).

\subsection{Instruments}

Survey questionnaire was in the data collection for this research. It involved both nominal and continuous measures. Strong support was achieved for the instruments with reliability alpha levels above the .60 threshold (Nunnally, 1970). The questionnaires contained the demographic variables of age and education, in addition to the measures of psychological capital (locus of control and self-efficacy) and innovative behaviour.

Locus of control scale which consisted of 10-item developed by Paulhus (1983) was used for this study. It originally had a mean of 51.8 for male and 52.2 for females with SD of 6 for both females and males. With a 5-point Likert response format ranging from (1) strongly disagree to (5) strongly agree, the scale indicates the higher the score above average, the more internal and the lower the score below average the more the external. The scale had a Cronbach alpha coefficient of .96. For Self-efficacy scale, Schwarzer and Jerusalem's (1993, 2000) 10-item modified measure of self-efficacy regarding entrepreneurial tasks was adopted. This measure of self-efficacy was significantly and moderately related to general self-efficacy. A 5-point Likert scale was used, ranging from 1 (no confidence) to 5 (complete confidence). It has a Cronbach alpha of .89. The individual innovative behaviour scale, was originally developed by Scott and Bruce (1994) as a 9-item scale and increased as 12 -items, was modified for use in this study. It is a self-rated measure of individual intentional efforts directed towards creativity as well as introducing and applying new ideas within an enterprise role. Finally, a 10-item with a 5-point Likert response format ranging from 1 (never) to 5 (always) was used. It also has a Cronbach alpha of 0.87 . 


\subsection{Procedure}

Questionnaires were administered to the respondent at their organizational site within Ibadan, Southwestern Nigeria with a letter of introduction. Participation was voluntary and confidentiality of responses was assured. The participants had the choice of responding to the questionnaires immediately or later; however, while some filled and returned the questionnaire the same day, others gave appointment for days to come for the questionnaire. The questionnaire administration took about eight-week. Not returning and incomplete questionnaires reduced the usable responses to 405 .

\section{Results}

The raw data obtained from the field by questionnaires were subjected to statistical analysis to confirm or discard the stated hypotheses. The detailed result of the statistical analysis is presented according to the stated hypothesis. First, the means, standard deviations, and correlations for all variables are shown in Table 4.1. In the table, locus of control and self-efficacy were significant correlated with each other and with entrepreneurial innovative behaviour.

(Insert table 4.1)

The first, second and third hypothesis examined the main and interaction effect of the psychological capital (locus of control and self-efficacy) on entrepreneurial innovative behaviour. The results in table 4.2 showed the mean values of all the factors as table 4.3 showed the summary results of 2 by 2 ANOVA. The tables of results (4.2 and 4.3) showed that women with internal locus of control $(\chi=72.79)$ significantly scored higher on entrepreneurial innovative behaviour than women with external locus of control $(\chi=34.58), \mathrm{F}(1,401)=403.00 \mathrm{p}<0.05$.

(Insert table 4.2)

Similarly, there was significant mean difference between women with high self-efficacy $(\chi=71.3)$ and those with low self-efficacy $(\chi=48.94)$ on entrepreneurial innovative behaviour $(F(1,401)=41.71 \mathrm{p}<0.05)$. While there was statistically significant two-way interaction effects between locus of control and self-efficacy on innovative behaviour among the women entrepreneurs $(\mathrm{F}(1,401)=78.49<.05)$.

\section{(Insert table 4.3)}

Figure 4.1 illustrates the pattern of the two-way interaction effects between locus of control and self-efficacy on entrepreneurial innovative behaviour. Women under the conditions of internal locus of control and low self-efficacy $(\chi=$ 75. 07) were the highest scorer on entrepreneurial innovative behaviour whereas the score of women under the condition of external locus of control and low self-efficacy $(\chi=34$. 01) were the lowest on entrepreneurial innovative behaviour. It implies therefore that individual differences tend to be more pronounced on internal locus of control in terms of these psychological capitals on entrepreneurial innovative behaviour than high self-efficacy dispersion.

(Insert Figure 4.1)

Table 4.4 showed that there was significant difference between the educational status of lowly educated certificate holders $(\chi=36.02)$ and the highly educated certificate holders $(\chi=71.94)$ on entrepreneurial innovative behaviour $(\mathrm{t}=$ $-40.34, \mathrm{p}<.000)$, indicating that education influences entrepreneurial innovative behaviour.

(Insert table 4.4)

\section{Discussion}

In this study, all the tested variables were statistically significant on entrepreneurial innovative behaviour among women entrepreneurs. First, the finding from this study provides evidence that there are strong relationship between the psychological capitals of self-efficacy, locus of control and entrepreneurial innovative behaviour. Linking this findings to Vroom's (1964) expectancy theory, it implied that the women entrepreneurs could have been influenced by the desire to grow (valence), with the perceived probability that entrepreneur innovative behaviour would lead to achievement of enterprise growth (instrumentality) and that innovativeness would have a desired effect on their business venture (expectance).

The findings also clearly showed that being internally controlled influenced entrepreneurial innovative behaviour among women entrepreneurs. Thus, confirming previous research that demonstrated strong linkages between locus of control and behaviour in areas such as entrepreneurship (Lefcourt 1981; Rauch \& Frese 2000; Sia et al., 1985; Van Kooten, et.al., 1986). Probably the findings came out like this because as (Rauch \& Frese, 2000) stated business owners have a slightly higher internal locus of control than others. It may be that being internally control makes it possible for the women to engage in entrepreneurial activities and may have subsequent empower them to be innovative. For according to Gist (1989), individuals with a strong internal locus of control tend to see opportunities to improve their skill base and have the confidence to try new techniques and technologies. It can be presumed therefore that being internally controlled might have contributed towards women's high score entrepreneurial innovative behaviour. Thus, it means that internal locus of control could be a significant when considering innovativeness among women entrepreneurs.

The findings of hypothesis, which sought to find difference in the level of self-efficacy, revealed that high self-efficacy is 
a significant factor on women entrepreneurial innovative behaviour. Hence, it confirms the studies such of Bandura (1997), Bandura, et al. (1999) and Sequeira, et al., (2007) that high self-efficacy is essential to most human performance. It also led credence to Wood and Bandura, (1989) assertion that high self-efficacy expectations regarding performance in a specific behavioural setting lead individuals to approach a situation such as entrepreneurial innovativeness. The significant effect of interaction between locus of control and self-efficacy suggests a further confirmation of previous research, which indicated that individuals with strong internal locus of control tend to be self-confident and will tend to exhibit high self-efficacy or mastery (Bandura 1997; Pearlin \& Schooler 1978). Other findings from this study showed that education is one of the significant factors that lead to entrepreneurial innovative behaviour. A possible explanation for this finding is that higher educational attainment (Bussey \& Bandura, 1999) could have played a significant influence on women entrepreneurs' social learning. Thus making them to overcome what Hackett and Betz (1981), called the limiting factors to full attainment of one's potentials.

\section{Conclusion}

Considering the result of the study, it could be construed that internal locus of control is the most significant factor in entrepreneurial innovative behaviour. In addition the study also highlighted the significant roles of possession of higher education and high self-efficacy among women entrepreneurs. These attributes might have propelled the women's belief in their ability to make things work and try out new styles and strategies on their enterprises without fear of failure.

With most empirical research, our study has a number of limitations. First, studying individual innovative behaviour in a natural work context is a complex and difficult task because the criterion is often difficult to validate, and researcher is often limited to the use of perceptual measures. Perhaps this is why there has been little research done in this area. Secondly, the current study relies on survey data, and thus, it is not as rigorous testing an experiment in a pure laboratory setting. Thirdly, this study did not separate the two-stages, which capture innovative behaviour (that is, initiation and implementation of ideas). Nevertheless, future studies should separate them into measures reflecting the task specific problems each poses. For a fuller understanding of this phenomenon, in-depth qualitative and quantitative research is required in addition to also incorporate other kinds of cognitive and behavioural factors that may affect women entrepreneurial innovative behaviour.

Although the findings reported here provide some guidance to practicing entrepreneurs, they also pose a completely new set of questions for researchers. Is there a threshold level at which additional factors no longer improve innovative behaviour? Is this effect common to all entrepreneurs in different sectors? Answers to these questions also await further study. Limitations notwithstanding, our findings suggest that there are significant differences in factors determining women entrepreneurial innovative behaviour. It also draws attention to the need, that women entrepreneurs should continually assess their level of innovativeness to seek for knowledge where there are deficiencies. Finally, it is expected that this study will further aid policy makers and women entrepreneurial training programs to stimulate ability, which are intrinsic in individuals for the exhibition of entrepreneurial innovative behaviour.

\section{References}

Acs, Z. J., \& Audretsch, D. B. (1999). Small firms and entrepreneurship: An East-West perspective. Cambridge: Cambridge University Press.

Babalola, S. S. (1998). Psychosocial determinants of self-employment behavior and perceived business success. An unpublished Ph.D Thesis in Department of Psychology, University of Ibadan, Ibadan.

Babalola, S. S. (2006). Managing innovation, product development and entrepreneurship. In S. Balogun, B. Ehigie, \& A. Sunmola (Eds.), Managerial psychology: An overview. Nigeria: University of Ibadan, Department of Psychology Publication. pp. 352-387.

Bandura, A. (1982). Self-efficacy mechanism in human agency. American Psychologist, 37 (2), 122-147.

Bandura, A. (1995). Self-efficacy in changing societies. New York: Cambridge University Press.

Bandura, A. (1997). Self-efficacy: The exercise of control. New York: Freeman.

Bandura, A. (2002). Social cognitive theory in cultural context. Journal of Applied Psychology: An International Review, 51, 269-290.

Bandura, A., Pastorelli, C., Barbaranelli, C., \& Caprara, G. (1999). Self-efficacy pathways to childhood depression. Journal of Personality and Social Psychology, 76, 258-269.

Berger, M., \& Byvinie, M. (1989). Women's ventures. West Hartford, CT: Kumarian Press.

Brush, C. G. (1992). Research on women business owners: Past trends, a new perspective and future directions. Entrepreneurship Theory and Practice, 16 (4), 5-30.

Bussey, K., \& Bandura, A. (1999). Social cognitive theory of gender development and differentiation. Psychological Review, 106, 676-713 
Cliff, J. E. (1998). Does one size fit all? Exploring the relationship between attitudes towards growth, gender, and business size. Journal of Business Venturing, 13 (6), 523-542.

Cooper, A. C., \& Gascon, F. (1992). Entrepreneurs, processes of founding and new-firm performance. In D. Sexton, \& J. Kasarda (Eds.), The state of the art of entrepreneurship. Boston: PWS-Kent.

Covin, J. G., \& Slevin, D. P. (1991). A conceptual model of entrepreneurship as firm behaviour. Entrepreneurship Theory and Practice, 16 (1), 7-25.

Craig, A. R., Franklin, J. A., \& Andrew, S. C. (1984). A scale to measure locus of control of behaviour. British Journal of Medical Psychology, 57, 173-180.

de Jong, J., \& den Hartog, D. (2003). Leadership as a determinant of innovative behaviour: A conceptual framework. Report published under the Scientific AnaLyses of Entrepreneurship SMEs (SCALES) initiative, Research Report H200303, Zoetermeer, EIM.

de Noble, A., Jung, D., \& Ehrlich, S. (1999). Entrepreneurial self-efficacy: The development of a measure and its relationship to entrepreneurial action. In Frontiers of entrepreneurship research. Boston, MA: Babson College.

Dickerson, A., \& Taylor, A. (2000). Self-limiting behaviour in women: Self esteem and self efficacy as predictors. Group and Organization Management, 25 (2), 191-210.

DTI, (2001). UK competitiveness indicators. (2nd ed.). London: HMSO.

Eden, D. (1992). Leadership and expectations: Pygmalion effects and other self-fulfilling prophecies in organizations. Leadership Quarterly, 3 (4), 271-305.

Ehigie, B. O., \& Idemudia, V.O. (2000). Working women and exclusive breastfeeding in Oyo State, Nigeria. African Journal of Business and Economic Research, 1(1), 49-57.

Ehigie, B. O., \& Umoren, U. E. (2003). Psychological factors influencing perceived entrepreneurial success among Nigerian women in small-scale businesses. Journal of International Women's Studies, 5(1), 78-95.

Ehigie, B. O. (2000). Gender differences in career orientation and influence on marital satisfaction, Ilorin Journal of Business and social Sciences, 6(2), $1-13$.

Erdil. S., Erdil, O., \& Keskin, H. (2004). The Relationship between market orientation, firm innovativeness and innovation performance. Journal of Global Business and Technology, 1(1), 1-11.

Gist, M. (1989). The influence of training method on self-efficacy and idea generation among managers. Personnel Psychology, 42, 787-805.

Gist, M. E. (1987). Self-efficacy: Implications for organizational behaviour and human resource management. Academy of Management Review, 12, 472-485.

Hackett, G., \& Betz, N. E. (1981). A self-efficacy approach to the career development of women. Journal of Applied Social Psychology, 30, 2137-2157.

Hoffman, R. R. (1974). Perceived obligations for career development: A comparison of responses of individuals who differ in managerial status and locus of control beliefs. Unpublished Doctoral Dissertation, The George Washington University.

Kalleberg, A. L., \& Leicht, K. T. (1991). Gender and organizational performance: Determinants of small business survival and success. Academy of Management Journal, 34 (1), 136-161.

Kanter, R. (1988). When a thousand flowers bloom: Structural, collective, and social conditions for innovation in organizations. In B. M. Staw, \& L. L. Cummings (Eds.), Research in organizational behaviour. Greenwich, CT: JAI Press. Vol. 10, pp. 169-211.

Kitching, B., \& Woldie, A. (2004). Female entrepreneurs in transitional economies: A comparative study of businesswomen in Nigeria and China. In Proceedings Hawaii international conference on business, Honolulu, Hawaii.

Lee, J-H., \& Venkataraman, S. (2006). Aspirations, market offerings, and the pursuit of entrepreneurial opportunities. Journal of Business Venturing, 21(1), 107-124.

Lefcourt, H. M. (Ed.). (1981). Research with the locus of control constructs Vol. 1: Assessment methods. London: Academic Press.

Loveman, G., \& Sengenberger, W. (1991). The re-emergence of small-scale production: An international comparison. Small Business Economics, 3 (1), 1-39.

Mabogunje, A. L. (1967). The morphology of Ibadan. In P. C. Lloyd, A. L. Mabogunje and B. Awe, (Eds.), The city of Ibadan. London: Cambridge University Press. 
McNairn, J. B., \& Mitchell, B. (1992). Locus of control and farmer orientation: Effects on soil conservation adoption. Journal of Agricultural and Environmental Ethics, 5, 87-101.

Mumford, M. D., \& Gustafson, S. B. (1988). Creativity syndrome: Integration, application, and innovation. Psychological Bulleting, 103, 27-43.

National Planning Commission. (NPC, 2004). National economic empowerment and development strategy (NEEDS), National Planning Commission, Abuja, Nigeria.

Nunnally, J. C. (1970). Introduction to psychological measurement. New York: McGraw Hill.

Orser, B., \& Hogarth-Scott, S. (2003). Opting for growth: Gender dimensions of choosing enterprise development. Canadian Journal of Administrative Sciences, 19 (3), 284-300.

Parikh, I. (1987). Women in management: An annotated bibliography with emphasis on commonwealth sources. London, Commonwealth Secretariat.

Paulhus, D. L. (1983). Sphere specific measures of perceived control. Journal of Personality and Social Psychology, 44, 1253-1265.

Pearlin, L. I., \& Schooler, C. (1978). The structure of coping. Journal of Health and Social Behaviour, 19, 2-21.

Quince, T., \& Whittaker, H. (2003). Entrepreneurial orientation and entrepreneurs' intensions and objectives. A CBR research program 3 on small and medium-sized enterprises, Working Paper No. 271, ESRC Centre for Business Research, University of Cambridge.

Rauch, A., \& Frese, M. (2000). Psychological approaches to entrepreneurial success: A general model and an overview of findings. In C. L. Cooper, \& I. T. Robertson, (Eds.), International review of industrial and organizational psychology. Chichester: Wiley. pp. 101-142.

Schiller, B. R., \& Crewson, P. E. (1997). Entrepreneurial origins: A longitudinal inquiry. Economic Inquiry, 35 (3), 523-531.

Schwarzer, R., \& Jerusalem, M. (1993). The general self-efficacy scale (GSE). [Online] Available: http://userpage.fu-berlin.de/ health/engscal.htm.

Schwarzer, R., \& Jerusalem, M. (2000). Generalized self-efficacy scale. [Online] Available: http://www.fu-berlin.de/gesund/skalen/procop_engl.htm.

Scott, S. G., \& Bruce, R. A. (1994). Determinants of innovative behaviour: A path model of individual innovation in the workplace. The Academy of Management Journal, 37 (3), 580 - 607.

Sequeira, J., Mueller, S. L., \& Mcgee, J. E. (2007). The influence of social ties and self-efficacy in forming entrepreneurial intentions and motivating nascent behaviour. Journal of Developmental Entrepreneurship, 12 (3), 275-293

Sia, A. P., Hungerford, H. R., \& Tomera, A. N. (1985). Selected predictors of responsible environmental behaviour: An analysis. Journal of Environmental Education, 17, 31-40.

UNIDO (2001). Women entrepreneurship development in selected African Countries. Working paper, No.7.

Van de Ven, A. (1986). Central problems in the management of innovation. Management Science, 32, 590-607.

Van Kooten, G. C., Schoney, R. A., \& Hayward, K. A. (1986). An alternative approach to the evaluation of goal hierarchies among farmers. Western Journal of Agricultural Economics, 11, 40-49.

Verheul, I., Uhlaner, L., \& Thurik, R. (2005). Business accomplishments, gender and entrepreneurial self-image. Journal of Business Venturing, 20, 483-528.

Vroom, V. H. (1964). Work and motivation. New York: Wiley.

Weiner, B. (1974). Achievement motivation and attribution theory. Morristown, N.J: General Learning Press.

West, M., \& Farr, J. (1989). Innovation at work: Psychological perspectives. Social Behaviour, 4, 15-30.

Wood, R., \& Bandura, A. (1989). Social cognitive theory of organizational management, Academy of Management Review, 14, 361-381.

World Bank. (1995). Enhancing women's participation in economic development. Washington, DC.

Zhao, H., Scott, E. S., \& Hills, G. E. (2005). The mediating role of self-efficacy in the development of entrepreneurial intentions. Journal of Applied Psychology, 90 (6), 1265-1272. 
Table 1. Showing the correction matrix between the psychological capitals and women entrepreneurial innovative behaviour

\begin{tabular}{|l|r|r|l|l|l|}
\hline & $\mathrm{N}$ & $\mathrm{X}$ & \multicolumn{1}{|c|}{ Locus of control } & Self-efficacy & EIB \\
\hline Locus of control & 405 & 38.39 & - & - & - \\
\hline Self-efficacy & 405 & 29.09 & $.166(* *)$ & - & - \\
\hline EIB & 405 & 43.59 & $.268(* *)$ & $.858(* *)$ & - \\
\hline
\end{tabular}

NOTE: $* *=\mathrm{P}<0.01 ; *=\mathrm{P}<0.05 ; \mathrm{EIB}=$ Entrepreneurial innovative behaviour.

Table 2. Summary table showing the means of the psychological capitals on women entrepreneurial innovative behaviour

\begin{tabular}{|l|l|l|l|l|}
\hline Locus of control & Self-efficacy & X & SD & N \\
\hline \multirow{5}{*}{ External } & Low & 34.01 & 6.65 & 147 \\
\cline { 2 - 5 } & High & 55.75 & 8.13 & 004 \\
\cline { 2 - 5 } & Total & 34.59 & 7.52 & 151 \\
\hline \multirow{5}{*}{ Internal } & Low & 75.07 & 4.08 & 84 \\
\cline { 2 - 5 } & High & 71.66 & 4.69 & 170 \\
\cline { 2 - 5 } & Total & 72.79 & 4.77 & 254 \\
\hline \multirow{5}{*}{ Total } & Low & 48.94 & 20.63 & 231 \\
\cline { 2 - 5 } & High & 71.29 & 5.32 & 174 \\
\cline { 2 - 5 } & Total & 58.54 & 19.42 & 405 \\
\hline
\end{tabular}

Table 3. Summary of 2 X 2 ANOVA showing the main and interaction effect of psychological capitals on women entrepreneurial innovative behaviour

\begin{tabular}{|l|c|c|c|c|c|}
\hline Source & SS & Df & MS & F & P \\
\hline Locus & 11820.79 & 1 & 11820.79 & 403.00 & $<.001$ \\
\hline Efficacy & 1223.56 & 1 & 1223.56 & 41.71 & $<.001$ \\
\hline Locus and Efficacy & 2302.26 & 1 & 2302.26 & 78.49 & $<.001$ \\
\hline Error & 11762.18 & 401 & 29.33 & & \\
\hline Total & 1540755.00 & 405 & & & \\
\hline
\end{tabular}

Table 4. Showing the t-test analysis the educational differences on women entrepreneurial innovative behaviour

\begin{tabular}{|l|l|l|l|l|l|l|l|}
\hline & Education & $\mathrm{N}$ & $\chi$ & $\mathrm{SD}$ & $\mathrm{df}$ & $\mathrm{t}$ & Sig. \\
\hline \multirow{2}{*}{$\begin{array}{l}\text { Innovative } \\
\text { behaviour }\end{array}$} & Primary/Secondary & 151 & 36.02 & 10.30 & 403 & -40.34 & .000 \\
\cline { 2 - 8 } & Tertiary & 254 & 71.94 & 7.53 & & & \\
\hline
\end{tabular}




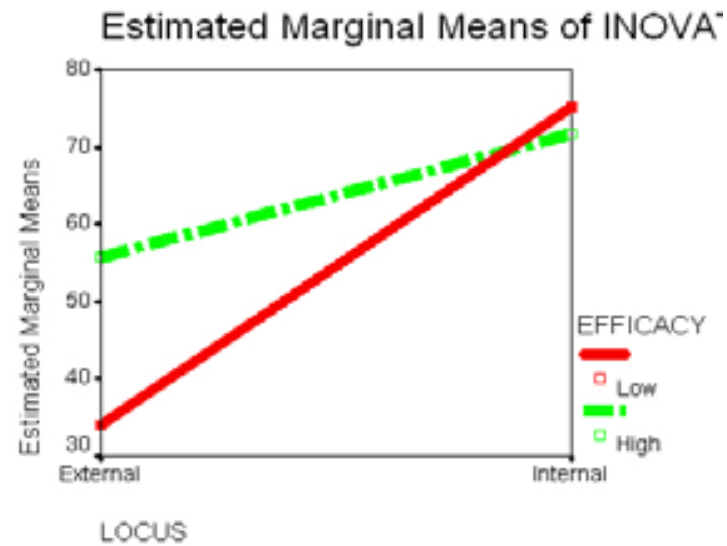

Figure 1. Graphical representation of the interaction effect of psychological capitals on women entrepreneurial innovative behaviour 